\title{
Evidence for an Early-Middle Miocene age of the Navidad Formation (central Chile): Paleontological, paleoclimatic and tectonic implications
}

\author{
Néstor M. Gutiérrez ${ }^{1,2}$, Luis F. Hinojosa ${ }^{1}$, Jacobus P. Le Roux ${ }^{2 *}$, Viviana Pedroza ${ }^{3}$ \\ 1 Laboratorio de Paleoecología, Facultad de Ciencias-Instituto de Ecología y Biodiversidad (IEB), Universidad de Chile, Las Palmeras \\ 3425, Santiago, Chile. \\ gutierrezn@ug.uchile.cl; Ifhinojosa@uchile.cl \\ 2 Departamento de Geología, Facultad de Ciencias Físicas y Matemáticas, Universidad de Chile/Centro de Excelencia en Geoter- \\ mia de los Andes, Plaza Ercilla 803, Santiago, Chile. \\ jroux@cec.uchile.cl \\ 3 Escuela de Ingeniería Geológica, Facultad Seccional Sogamoso, Universidad Pedagógica y Tecnológica de Colombia. \\ viviana.pedroza@uptc.edu.co \\ * Corresponding author
}

\begin{abstract}
The age of the Navidad Formation in central Chile has always been controversial, mainly due to the conflicting age ranges indicated by its macro- and microfossils. Macrofossils are generally interpreted as having been reworked from older, Early to Middle Miocene strata, whereas a Late Miocene-Pliocene age has been accepted on the basis of planktonic foraminifer index species. The results of this study, however, indicate that the macrofossils occur in situ, which necessitates a complete revision of the geochronological data. It is concluded that the evidence for an Early to Middle Miocene age is overwhelming, and that the planktonic foraminifer index species must have appeared in the SE Pacific earlier than elsewhere. These include Globoturborotalia apertura, Globorotalia puncticulata (Deshayes), Globorotalia spheriomizea (Walters), Neogloboquadrina pachyderma (Ehrenberg), and Neogloboquadrina acostaensis (Blow). An Early to Middle Miocene age for the Navidad Formation correlates well with a reinterpretation of its depositional environment as a continental shelf instead of a deepwater continental slope, global and regional paleoclimatic events, and the tectonic development of the Andes Range.
\end{abstract}

Keywords: Foraminifer index species, Middle Miocene Climatic Optimum, Andean tectonics, Arid Diagonal.

RESUMEN. Evidencias de una edad miocena temprana-media de la Formación Navidad: Implicancias paleontológicas, paleoclimáticas y tectónicas. La edad de la Formación Navidad en Chile central siempre ha sido controversial, debido a los distintos rangos de edad indicados por los macro- y microfósiles. En general, se considera que los macrofósiles han sido retrabajados de estratos del Mioceno Temprano a Medio, y se aceptó una edad miocena tardía para esta unidad sobre la base de especies indicadoras de foraminíferos planctónicos. Sin embargo, los resultados de este estudio indican que los macrofósiles ocurren in situ, lo cual hace necesario una revisión completa de los datos geocronológicos. Se concluye que la evidencia por una edad miocena temprana a media es contundente, y que los foraminíferos planctónicos que indicarían una edad miocena tardía aparecieron más temprano en el SE del océano Pacífico que en otras partes. Estos foraminíferos incluyen Globoturborotalia apertura, Globorotalia puncticulata (Deshayes), Globorotalia spheriomizea (Walters), Neogloboquadrina pachyderma (Ehrenberg), y Neogloboquadrina acostaensis (Blow). Una edad miocena temprana a mediana correlaciona bien con la reinterpretación del ambiente deposicional como una plataforma continental en vez de un talud continental con agua profunda, eventos paleoclimáticos reconocidos a escala global y regional, y el desarrollo tectónico de los Andes. 


\section{Introduction}

The Navidad Formation in central Chile (Fig. 1), since first described by Darwin (1846), has attracted considerable attention over the years due to its wealth of fossils, which include well preserved leaves and pollen (e.g., Troncoso, 1991; Meón et al., 1994; Hinojosa, 2005), microfossils such as foraminifera and ostracods (Osorio, 1978; Martínez-Pardo, 1990; Ibaraki, 1992; Finger et al., 2003) and macrofossils ranging from gastropods to crustaceans and sharks (Philippi, 1887; Tavera, 1960; Nielsen et al., 2004; Feldmann et al., 2005; Suárez et al., 2006). However, it is precisely this abundant variety of fossils that has led to considerable debate on the age of this formation, which has been assigned to the Late Oligocene-Early Miocene based on invertebrate macrofossils (Tavera, 1979), the Late Miocene according to ostracods (Osorio, 1978) and the Middle Miocene-early Pliocene due to the presence of certain foraminifer index species (Encinas et al., 2006; Finger et al., 2007). Strontium dating of shells, on the other hand, has consistently yielded Early-Middle Miocene ages (Encinas, 2006). Nielsen et al. (2003), Encinas et al. (2008) and Finger et al. (2007) attributed this discrepancy to the reworking of older, shallow water micro- and macrofossils into deep water, where they were mixed with the younger foraminifers.

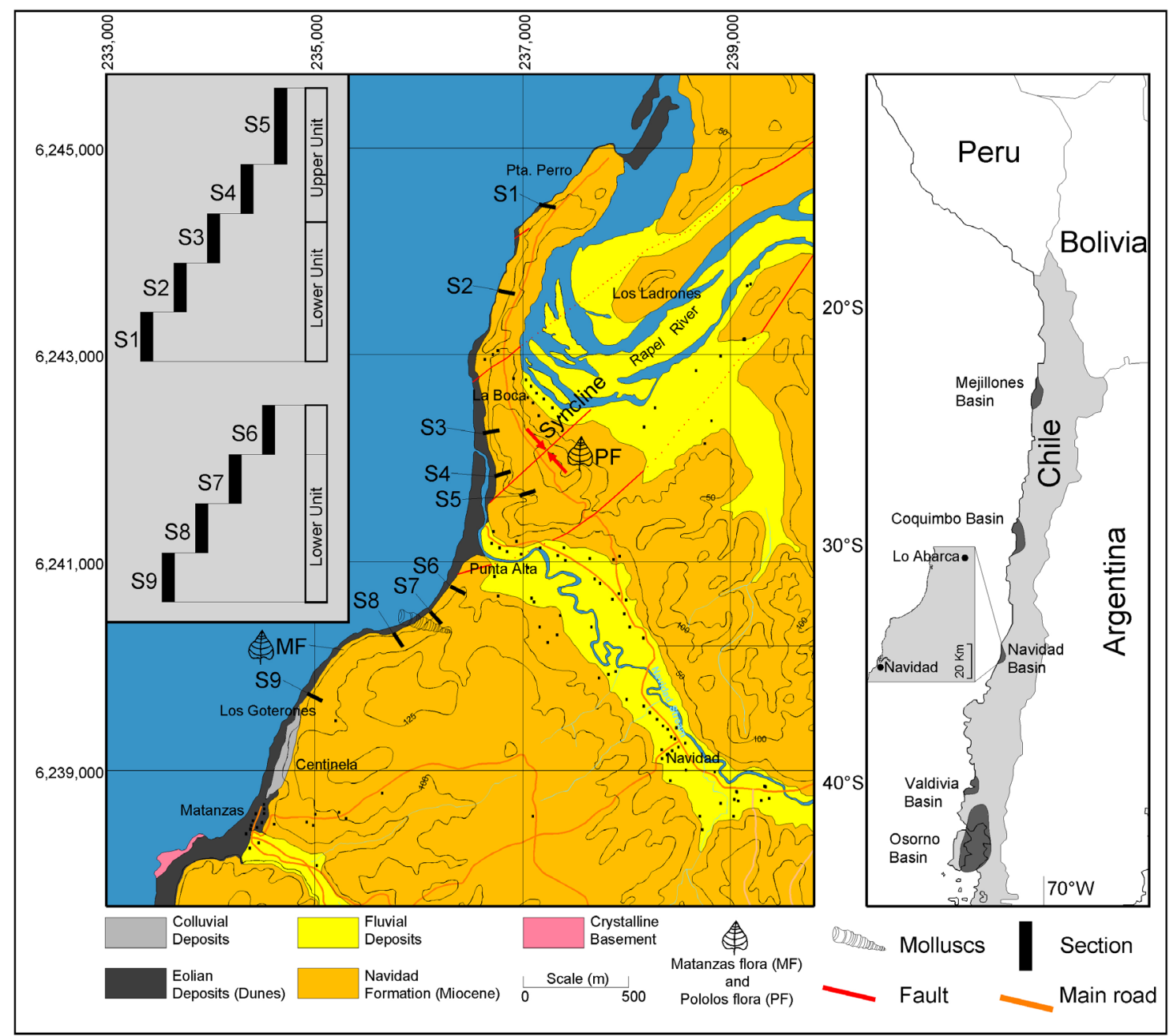

FIG. 1. Geological and locality map showing places mentioned in text. Locations of measured stratigraphic sections are indicated as S1-S9. 
Not only the age of the Navidad Formation have been controversial, but also its stratigraphic extent and subdivision (Table 1) as well as its depositional environment. The latter has generally been interpreted as shallow marine (e.g., Tavera, 1979), although Encinas (2006) and Encinas et al. (2008) proposed water depths reaching up to $1,500 \mathrm{~m}$ based on benthonic foraminifers. For the purposes of this paper, the stratigraphic nomenclature of Encinas et al. (2006) is accepted (Table 1), although the possibility that this may have to be revised in the future cannot be discarded.

\section{The age of the Navidad Formation}

Various methods have been used to determine the age of the Navidad Formation, which are critically summarized below.

\subsection{Molluses}

In Peru, Navidad mollusc species such as Miltha vidali (Philippi), Acanthina katzi (Fleming), Olivancillaria claneophila (Duclos) and Testallium cepa (Sowerby) occur in well-dated strata of the Late Oligocene-Middle Miocene (Nielsen et al., 2003), but not in younger successions (Vermeij and DeVries, 1997; DeVries and Frassinetti, 2003). Other Navidad species such as Ficus distans (Sowerby) are restricted in Peru to the Early-Middle Miocene (Covacevich and Frassinetti 1980), whereas Eucrassatella ponderosa (Philippi), Glycymeris ibariformis (Frassinetti and Covacevich), and G. colchaguensis (Griffin and Nielsen) only occur in the Late Oligocene-Early Miocene (DeVries and Frassinetti, 2003). An Early Miocene age was also obtained by ${ }^{87} \mathrm{Sr} r{ }^{86} \mathrm{Sr}$ dating of 2 samples of $O$. claneophila from the Navidad Formation at its type locality, which yielded $24.7 \pm 0.4$ and $20.4 \pm 0.5 \mathrm{Ma}$ (Encinas, 2006). The youngest age among these species as indicated by Acanthina katzi is about $13 \mathrm{Ma}$ (Finger et al., 2007, Fig. 9). There are no published reports of exclusively Late Miocene molluscs in the Navidad Formation. In our opinion, there is clear evidence that these fossils had not been reworked. Many of the shells are extremely well preserved (Nielsen and Glodny, 2006), bivalves often being articulated and some molluscs

TABLE 1. LITHOSTRATIGRAPHY AND AGE OF THE NAVIDAD FORMATION AS PROPOSED BY PREVIOUS AUTHORS AND THIS PAPER.

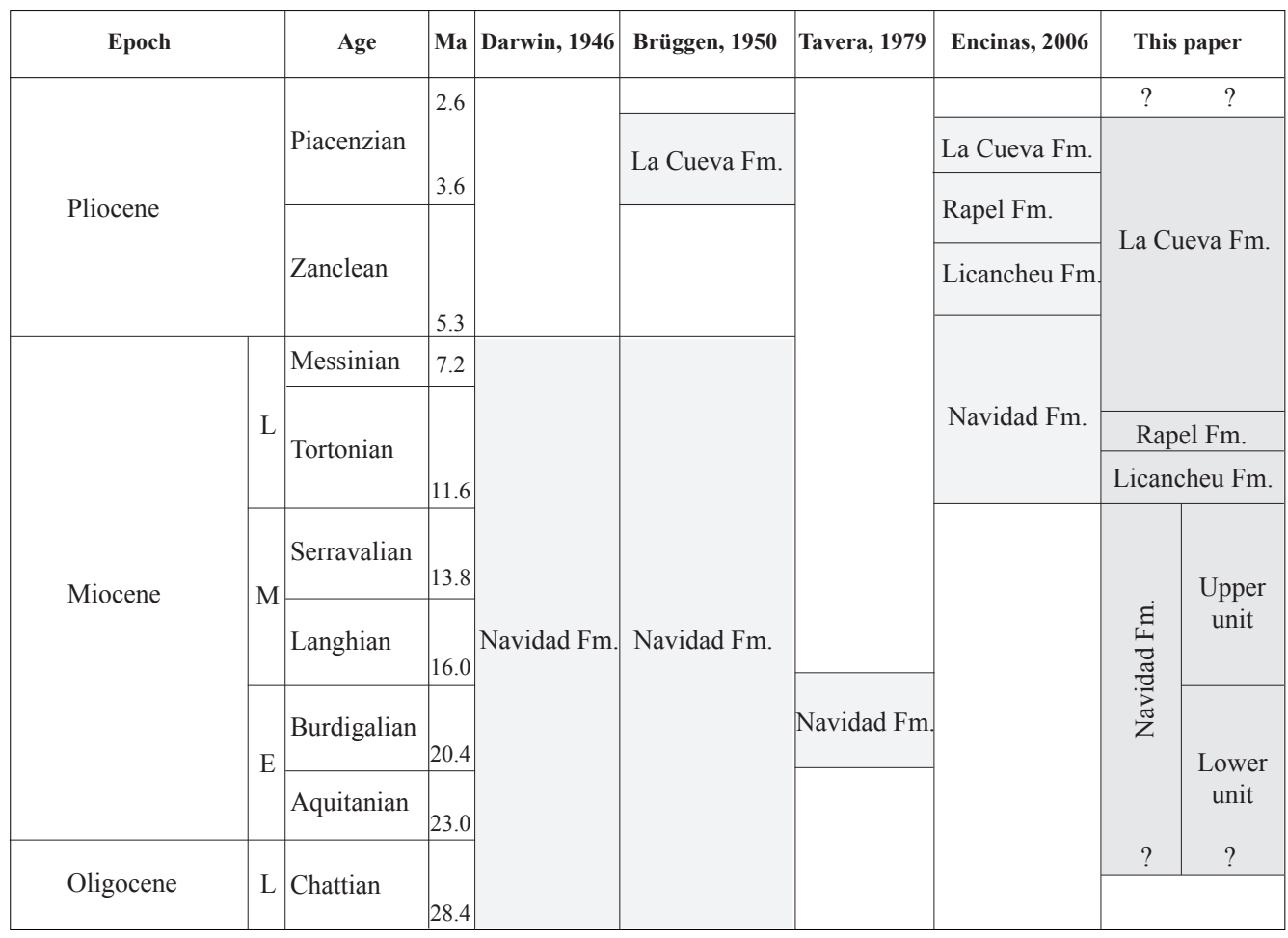


having delicate ornamentation. At least one species, Lucinoma promaucana, clearly occurs in situ at a paleo-seep in the Navidad Formation (Contardo and Mena, 2012). This bivalve family presently lives at hydrothermal vents and cold-seeps (Campbell and Bottjer, 1995) and was also dominant in Oligocene to Neogene paleo-seeps in the North Pacific (Kiel et al., 2010). The specific species $L$. promaucana has been recorded, apart from the Navidad Formation, only in the Oligocene of Argentina (Malumián et al., 1978) and on Hereford Island in Chile, where Covacevich and Frassinetti (1986) assigned it tentatively to the Middle Miocene. It would be too great a coincidence to accept that this species was reworked from older rocks in such a way that it coincides exactly with the paleo-seep occurrence.

The strongest evidence, however, is that the matrix filling all the molluscs that we have observed is the same as that of the host strata (Fig. 2). If these fossils had been reworked from older (by at least 1.4 million years) rocks into Late Miocene sediments, the original material would have been consolidated and should thus have been preserved within the shells, thus differing from that of the younger host matrix. In addition, Nielsen (2003) and Nielsen et al. (2003) mention that molluscs of different ecological environments are separated into well-defined units, shallow water fauna being present in sandstone and deeper water fauna in siltstone. This separation of inner- and outer shelf fauna could more logically be explained by sea-level oscillations producing lateral shifts in facies belts than by reworking, which would have mixed deep and shallow water species indiscriminately. Finally, if the Navidad Formation were of Late Miocene age, we consider it to be very strange that no molluscs of this age have been found within the strata, as there is no evidence of any abnormal marine conditions that would have prevented their occurrence. We consider therefore the mollusc fossils to have been preserved in situ and to reflect the true age of the host strata.

\subsection{Shark teeth}

Suárez et al. (2006) recorded the teeth of various elasmobranch species from the Navidad Formation. Among these is Carcharoides totuserratus (Ameghino), an uncommon shark with a chronostratigraphical range restricted to the Late Oligocene and Early Miocene (Suárez and Marquardt, 2001).

\subsection{Strontium dating}

Twenty-nine out of 30 molluscs dated by Encinas (2006) yielded ${ }^{87} \mathrm{Sr} /{ }^{86} \mathrm{Sr}$ ages between 31.5 and $16.0 \mathrm{Ma}$, with only one age falling within the earliest Late Miocene (11.5 $\pm 1.0 \mathrm{Ma})$. This sample was an oyster from the Lo Abarca sector (Fig. 1), which is probably not suitable for this kind of dating because oysters commonly occur in brackish water environments, in which the oceanic $\mathrm{Sr}$ content would be affected. In fact, Encinas (2006) mentions the presence of freshwater diatoms in samples from this sector.

Other $\mathrm{Sr}$ age determinations have been carried out on samples from the lower part of the Navidad Formation by K. Gregory-Wodziki and S. Pekar of the Columbia University as part of a pilot study. Twenty-four samples of shell material from the Navidad Formation yielded $\mathrm{Sr}$ ages between $23.0 \pm 0.6$ and 20.2 $\pm 0.6 \mathrm{Ma}$ (K. Gregory-Wodziki, personal communiation to Suárez et al., 2006). Furthermore, Nielsen and Glodny (2006) also reported $21 \mathrm{Sr}$ ages that range between 24.3 and 16.1 Ma.

Additionally, we dated 8 molluscs between 22.5 and 18.9 Ma (Table 2). All the shells were in excellent condition, as shown by color conservation, unbroken ornaments and preserved articulation in the case of bivalves. They contained the same matrix-fill as the surrounding sediment.

The Sr ages obtained so far (a total of 83 samples dated in different laboratories) thus confirm the ages given by the generally accepted chronostratigraphic ranges of the Navidad mollusc species, being overwhelmingly Early Miocene.

\subsection{Radiometric dating}

Encinas (2006) dated 6 volcanic scoria and pumice clasts in the Navidad Formation using the K-Ar and Ar/Ar geochronological methods. Five of these are of Early to Middle Miocene age (22.2-15.9 Ma) and only one yielded $11.06 \pm 0.19$ $\mathrm{Ma}$. We also dated 2 pumice clasts by $\mathrm{Ar} / \mathrm{Ar}$, obtaining ages of $16.41 \pm 0.45$ and $12.87 \pm 0.5 \mathrm{Ma}$. The generally well-rounded volcanic clasts occur in distinct, thin beds and therefore reflect specific, short-lived erosional events. Encinas (2006) argued that these clasts were also reworked from older strata. However, we contend that older beds would have been tilted by Andean uplift before the Late 


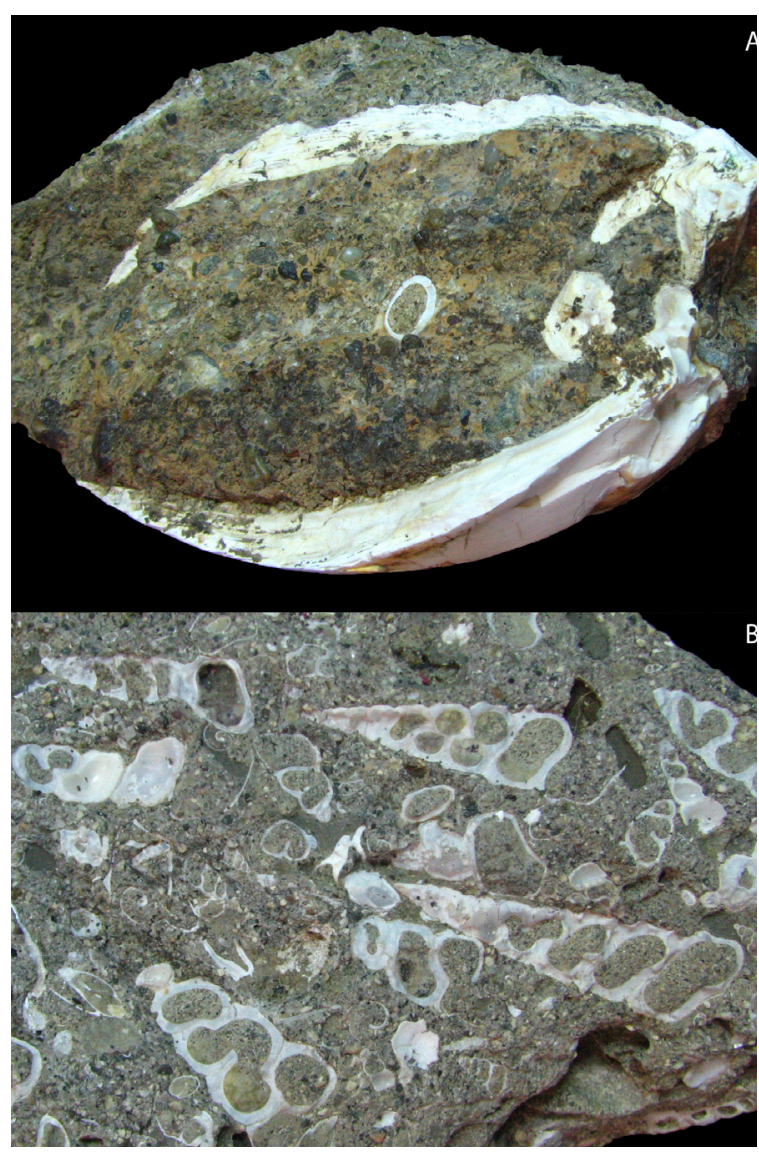

FIG. 2. Articulated bivalve (a) and gastropod (b) with trapped matrix similar to that of the surrounding host, which indicates that they are in situ. The material was left in the field at section S7 in figure 1.
Miocene, which upon erosion would have yielded volcanic clasts dispersed throughout the Navidad Formation. Conversely, if they were derived from surface scoria covering the landscape around volcanoes that erupted during the Early-Middle Miocene, the material would have been eroded rapidly during subsequent run-off events, arriving shortly thereafter in the Navidad Basin and thus reflecting the true age of the latter.

\subsection{Diatoms}

Only 2 of 15 samples analysed by Encinas (2006) for diatoms yielded index species, namely Crucidenticula punctata (Schrader) and Craspedodiscus coscinodiscus (Ehrenberg), which have age ranges of 12.8-11.3 Ma and 16.9-11.3 Ma, respectively (Barron, 2003). However, both samples came from the Lo Abarca sector, where the only Tortonian Srdate of $11.5 \pm 1.0 \mathrm{Ma}$ was also recorded. The Lo Abarca sector has mollusc species showing important differences with those of the type area at Navidad, which led Covacevich and Frassinetti (1990) to propose that these strata belong to a unit younger than the Navidad Formation. The diatoms may therefore not be diagnostic of the true age of the Navidad Formation, but in any case do not contradict an Early to Middle Miocene age.

TABLE 2. NEW ${ }^{87} \mathrm{Sr} /{ }^{86} \mathrm{Sr}$ AGES FOR THE NAVIDAD FORMATION, BASED ON THE CURVE OF McARTHUR AND HOWARD (2004).

\begin{tabular}{lllll}
\hline Sample & \multicolumn{1}{c}{ Description } & ${ }^{87} \mathbf{S r}{ }^{86} \mathbf{S r}$ & 2 sem (\%) & Age (Ma) \\
\hline M1 & Unidentified shell fragment & 0.708371 & 0.0013 & 21.0 \\
M2B & Turritella & 0.708468 & 0.0012 & 19.4 \\
M2A & Turritella & 0.708543 & 0.0012 & 18.4 \\
M3 & Gastropods and scaphopods & 0.708309 & 0.0014 & 21.9 \\
M4 & Gastropods & 0.708500 & 0.0013 & 19.0 \\
M5 & Bivalves & 0.708430 & 0.0015 & 19.9 \\
M7 & Gastropods and scaphopods & 0.708486 & 0.0014 & 19.2 \\
M8 & Bivalves & 0.708299 & 0.0010 & 22.1 \\
\hline
\end{tabular}

Stratigraphic locations of samples are indicated in figure 3. Age error ranges vary between 0.07 and $0.20 \mathrm{Ma}$. 


\subsection{Ostracods}

Osorio (1978) identified 7 ostracod species in the Navidad Formation, 4 of which do not occur after the Middle Miocene, namely Bythocypris gibsonensis (Howe and Chambers), Parakrithe vermunti, Hermanites reticulata, and Cytheropteron stictum. One species (Munseyella bermudezi) was assigned to the Late Miocene, and 2 species, namely Krithe bartonensis (Brady, Crosskey and Robertson), and Bradleya normani (Brady) belong to the Plio-Pleistocene. However, both Munseyella bermudezi and Krithe bartonensis have been recovered from Eocene strata elsewhere (Van den Bold, 1960; Elewa, 2004).

Encinas (2006) reported Krithe producta (Brady), $K$. reversa (Bold), Legitimocythere acanthoderma (Brady), Bythoceratina cf. B. scabra (Bold), Cardobairdia glabra (Bold), and Bradleya normani. Krithe producta occurs in Late Oligocene-Early Miocene deposits in Trinidad (Van den Bold, 1958), whereas the earliest known record of Krithe rever$s a$ is Middle Miocene (Coles et al., 1994). Of the other species, Legitimocythere acanthoderma has occurred since the Early Miocene (Guernet, 1998), Bythoceratina scabra is present in the Eocene and Oligocene of Trinidad (Van den Bold, 1960), and Cardobairdia glabra has been reported from the Early Miocene-Pliocene of the Caribbean (Van den Bold, 1974). Therefore only one ostracod species, Bradleya normani, has not yet been reported from Middle Miocene or older strata.

\subsection{Planktonic foraminifers}

Finger et al. (2007) identified the following planktonic foraminifer index species that they considered to be younger than 11.6 Ma (Late Miocene): Globoturborotalia apertura, Globorotalia puncticulata (Deshayes), Globorotalia spheriomizea (Walters), Neogloboquadrina pachyderma (Ehrenberg), and Neogloboquadrina acostaensis (Blow). The last species was dated by Encinas (2006) at 12.1 \pm 0.7 Ma using ${ }^{87} \mathrm{Sr} /{ }^{86} \mathrm{Sr}$.

The generally accepted Late Miocene to Pliocene age of the 5 species listed above appears to be the only evidence against an Early-Middle Miocene age for the Navidad Formation, the latter being supported by mollusc fossils, $\mathrm{Sr}$ and radiometric dating, and shark teeth, which is not necessarily being contradicted by the ostracods and diatoms.
Other foraminifers identified in the Navidad Formation by Encinas et al. (2008), such as Catapsydrax dissimilis (Cushman and Renz), are also known from the Oligocene-Early Miocene (Cushman and Renz, 1947; Blow, 1959). This suggests that either all these alternative dating methods are unreliable, or that the 5 foraminifer index species above appeared earlier in the southeast Pacific than elsewhere. If this is correct, it means that other new fossil species described from the Navidad Formation are of EarlyMiddle and not Late Miocene age (e.g., Nielsen and Frassinetti, 2003). This would also affect future fossil discoveries.

\subsection{Lithostratigraphy}

The $\mathrm{Sr}$ and radiometric dates are consistent with the stratigraphy of the Navidad Formation. Based on 9 measured stratigraphic profiles (Fig. 1), we subdivided the Navidad Formation into a lower and upper unit, with maximum thicknesses of 110 and $115 \mathrm{~m}$, respectively (Fig. 3). The lower unit is composed of coarse- to medium-grained sandstone interbedded with lenticular, pebbly sandstones, whereas the upper unit has fine- to very fine-grained sandstones intercalated with shales and claystones. The frequency of invertebrate fossils, large pumice clasts and wood fragments decreases significantly from the lower to upper unit. Our $\mathrm{Sr}$ and radiometric dating indicates ages of 26-16 Ma for the lower unit and 16-12 Ma for the upper unit.

\section{Implications for sedimentological environment, tectonism and paleoclimate}

An Early to Middle Miocene age for the Navidad Formation has important implications for paleontological studies, the depositional environment of the Navidad Formation, as well as tectonic and paleoclimatic interpretations of the southeastern Pacific seaboard.

\subsection{Depositional environment and tectonic events}

Encinas (2006) and Encinas et al. (2008) considered the Navidad Formation to have been deposited on the continental slope in water depths up to $1,500 \mathrm{~m}$, based on benthonic foraminifera (Bathysiphon, Melonis, Osangularia, Pleurostomella, and Siphonodosaria) together with trace fossils. 


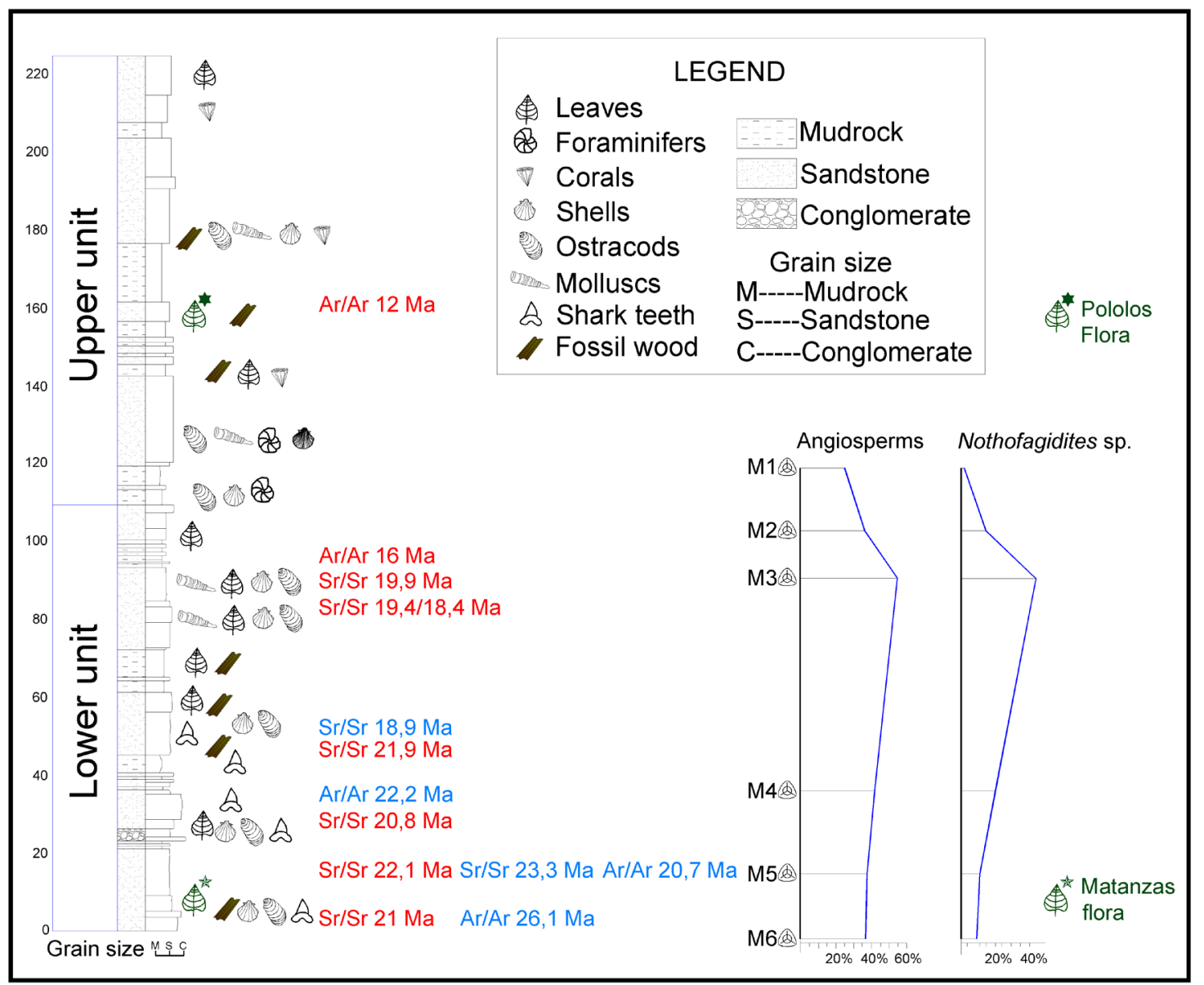

FIG. 3. Lithostratigraphy of the Navidad Formation showing subdivision into lower and upper unit and trends in pollen taxa. Dates shown in blue are those mentioned by Encinas (2006), in red are our own. Paleobotanic data shown in black are those of Hinojosa and Gutiérrez (2009).

Fossil benthonic foraminifers are commonly used in paleobathymetric studies based on the depth distribution of their closest living relatives (Lipps, 1993). However, these studies are most relevant for marine deposits post-dating the expansion of the Antarctic ice cap during the late Middle Miocene, when the oceans reached conditions similar to those of today. In the southeastern Pacific, major cooling only started during the Serravalian-Tortonian, i.e., after about 13.8 Ma (Le Roux, 2012a). New benthonic foraminifer species that evolved at this time began to inhabit different water depths due to the thermal stratification of the ocean waters (Kennett, 1982; Lipps, 1993) and can therefore be used in such paleobathymetric studies. However, this is much more problematic in the case of pre-Serravalian species
(Kennett, 1982; Lipps, 1993; Encinas, 2006), where such depth differentiation probably did not yet exist. If an Early to Middle Miocene age is accepted for the bulk of the Navidad Formation, this would cast serious doubt on the subsidence to water depths of up to $1,500 \mathrm{~m}$ inferred by Encinas et al. (2008) at the beginning of Navidad deposition.

The trace fossil suite described by Encinas (2006) includes Ophiomorpha nodosa (Lundgren), Skolithos linearis (Haldeman), Conichnus conicus (Männil), Macaronichnus segregates, and Thalassinoides isp., considered to represent an upper shoreface environment (Pemberton et al., 2001). Diplocraterion parallelum (Torell), Lophoctenium isp., Zoophycus isp., and Chondrites isp. also occur, which were attributed to a deepwater, continental slope environment 
(Encinas, 2006; Encinas et al., 2008). Whereas the last two ichnogenera are generally considered to be typical of the continental slope, it does not necessarily indicate water depths much greater than 150-200 m. Furthermore, Diplocraterion parallellum has been described from shallow water, restricted bay facies in Slovakia (Šimov and Olšavský, 2007), whereas dense concentrations of Chondrites have also been reported from shallow water settings, where they were linked to the burial of high quantities of organic matter during storm events (Vossler and Pemberton, 1988). Even Zoophycos ('Spirophyton') has been recorded in shallow subtidal deposits in South Africa (Boucot and Theron, 2001).

Encinas et al. (2008), using the planktonic foraminifer ages and water depth reconstructions based on benthonic foraminifers, proposed very rapid tectonic subsidence of at least $1,500 \mathrm{~m}$ at the beginning of the Tortonian (11.6 Ma), followed by equally rapid uplift to above sea-level at around $5 \mathrm{Ma}$. If our ages are correct, this would mean that such subsidence occurred around the Oligocene-Miocene transition and was inverted in the Early-Middle Miocene. However, we differ in our interpretation of paleowater depths for the Navidad Formation, considering the presence of wave ripples in the sandstones, the occurrence of delicate land insect wings and other body parts, and abundant, well-preserved fossil leaves, especially in the lower unit (Fig. 4). Pollen recovered by us from the Navidad Formation also consists of $99.7 \%$ continental palynomorphs and only $0.3 \%$ marine palynomorphs, which is inconsistent with a bathial environment. Taken together, these features suggest that the Navidad Formation represents a shallow coastal to outer shelf environment, in which sea-level oscillations or tectonic movements caused lateral migrations of facies belts. Finer-grained deposits and a decrease in the frequency of large wood and pumice fragments, leaves and palynomorphs in the upper unit indicate a general rise in sea-level commencing at about $16 \mathrm{Ma}$. This coincides with the beginning of marine transgression at around $15 \mathrm{Ma}$ and the greatest depositional water depths recorded between 12-11 Ma in the Coquimbo Basin (Le Roux et al., 2005), as well as a change from estuarine peat swamp conditions to deep marine embayments in the Valdivia and Osorno Basins (Fig. 1) during the Middle Miocene (Le Roux and Elgueta, 2000; Elgueta et al., 2005). Tectonic subsidence accompanied by marine transgression during the Middle Miocene thus affected around $1,000 \mathrm{~km}$ of coastline between $30^{\circ} \mathrm{S}-40^{\circ} \mathrm{S}$.

A general regressive succession commencing during the Late Miocene, is reflected in the shallow water deposits of the Licancheu Formation para-

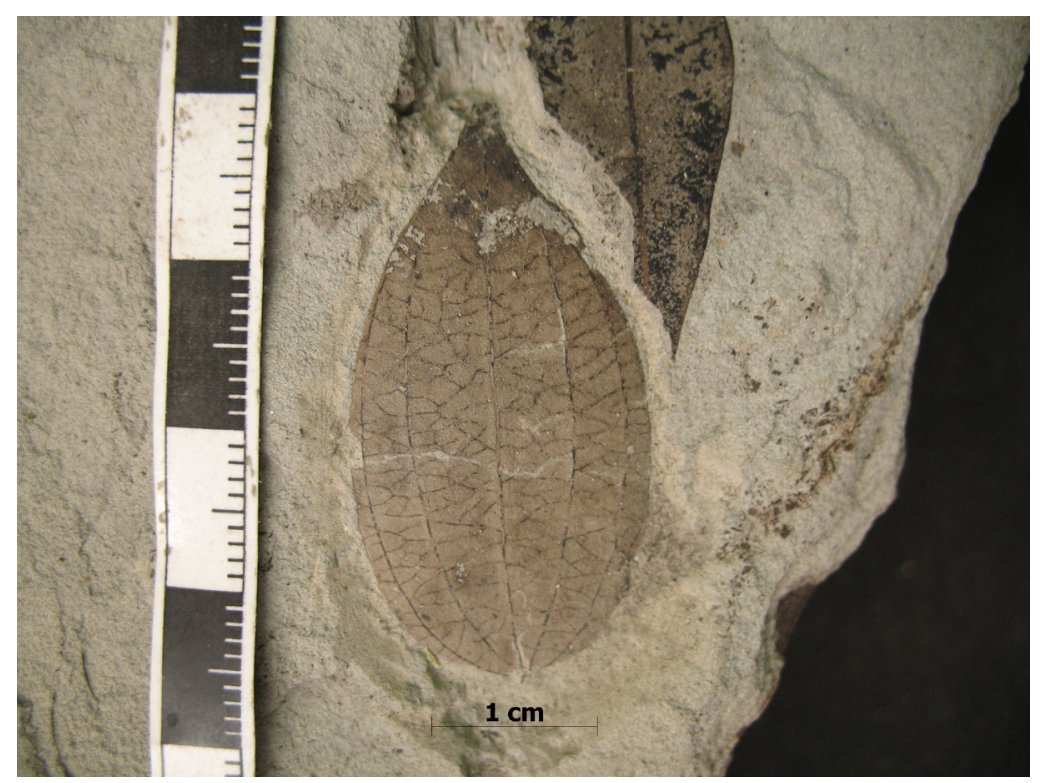

FIG. 4. Delicate, well preserved leaves (Melastomataceae) in the Navidad Formation, suggesting that deposition took place not far from land. Scale $=1 \mathrm{~cm}$. The material was left in the field at the locality marked as 'Matanzas Flora' in figure 1 . 
conformably overlying the Navidad Formation. The latter was considered by Encinas (2006) to be of Pliocene age based on its stratigraphic position above the Navidad Formation, older Sr dates (not specified) being discarded by him because of 'probable diagenetic alteration'. However, the Licancheu Formation is in turn overlain by the Rapel and La Cueva Formations (both with paraconformable contacts), the latter yielding radiometric ages on pumice clasts between 7.7 $\pm 1.0-2.7 \pm 0.3 \mathrm{Ma}$ (Encinas, 2006). If a Late Miocene-Pliocene age is accepted for the La Cueva Formation, it is likely that the Licancheu Formation is Late Miocene. This implies that general marine regression and tectonic uplift could have started soon after $11 \mathrm{Ma}$ along this part of the southeastern Pacific seaboard. Gregory-Wodziki (2000), based on various lines of evidence, concluded that the Altiplano of the central Andes had attained no more than half its modern elevation by $10.7 \mathrm{Ma}$, and that surface uplift of 2,300-3,400 m occurred since the Late Miocene. Bissig et al. (2002) also recognized an important erosional surface in the high central Andes that formed in the interval 10-6 Ma.

\subsection{Oceanic paleoclimatic conditions}

Gastropods in the Navidad Formation include many warm-water genera such as Nerita, Strombus, Sinum, Distorsio, Ficus, Zonaria, Olivancillaria, Terebra, Architectonica, and Heliacus (Covacevich and Frassinetti, 1986; Groves and Nielsen, 2003; Nielsen et al., 2004). Such (sub)tropical conditions were also identified elsewhere in the southeastern Pacific during the Early-Middle Miocene. MartínezPardo (1990) recorded a warming event between 18 and 11.5 Ma that extended north from $45^{\circ} \mathrm{S}$, based on the presence of foraminifers such as Globoquadrina venezuelana (Hedberg), Globigerinita glutinata (Egger), and the Globorotalia mayeri-G. siakensis plexus. These species are similar to those in tropical areas during the Early-Middle Miocene (Bertels, 1979; Srinivasan and Kennett, 1981; Kennett et al., 1985), indicating that oceanic circulation and temperature gradients of marine waters in the southeast Pacific were more uniform than those prevailing today. Tsuchi (1992) recorded a Middle Miocene Climatic Optimum that culminated around $16 \mathrm{Ma}$ in Japan and the southeast Pacific, which is also revealed by the presence of warm-water planktonic foraminifera in the Mejillones Basin (Martínez-Pardo, 1990;
Fig. 1) and the Coquimbo Basin (Martínez-Pardo, 1979). This is reinforced by the presence of typical equatorial diatoms such as Actinoptychus senarius (Ehrenberg), Actinocyclus ellipticus (Ehrenberg), and Coscinodiscus oculoiridis in the Coquimbo Formation (Martínez-Pardo and Caro, 1980), as well as at Mejillones (Martínez-Pardo, 1980). The sea surface temperature reached about $25^{\circ} \mathrm{C}$ at this time (Loutit et al., 1983).

Abrupt cooling of ocean water began at $15 \mathrm{Ma}$ in Japan and Peru (Tsuchi, 1992), but seems to have spread to the southeastern Pacific mainly during the Late Miocene (Le Roux, 2012a). Such colder oceanic conditions are clearly recorded in the Licancheu and Rapel Formations, where Covacevich and Frassinetti (1986) noted a significant decrease in the total number of mollusc genera and species. An age of about $7 \mathrm{Ma}$ for the La Cueva Formation would also coincide with the colder conditions and glaciations recorded between 7-5 Ma in West Antarctica and at Lago General Carrera in central Patagonia (Zachos et al., 2001; Lagabrielle et al., 2010).

\subsection{Continental paleoclimatic conditions}

From at least the late Paleocene to early Eocene, a subtropical, wet paleoclimate with high mean annual temperatures and a low mean variation range was recorded in southern Chile (Troncoso et al., 2002). Towards the end of the Eocene, this Subtropical Gondwana Paleoflora of southern South America was replaced by Mixed Paleoflora, which in turn gave way to Subtropical Neogene Paleoflora indicating hot, humid conditions during the Early-Middle Miocene (Hinojosa and Villagrán, 1997, 2005). Maximum continental temperatures were reached between 17-15 Ma, as indicated by fossil leaves and pollen of Miocene deposits in Chile and Argentina (Hinojosa, 2005; Hinojosa et al., 2011). After the Middle Miocene Climatic Optimum, pollen records suggest a marked decrease in temperature attributed to glaciation in West Antarctica and the beginning of uplift in the Andes (Zachos et al., 2001). This SerravalianTortonian cooling (Le Roux, 2012b) was apparently manifested in Chilean Patagonia by varves with dropstones interbedded with conglomerates that were correlated with nearby conglomerates (30 km apart) dated at $12 \mathrm{Ma}$ by zircons from an intercalated tuff (Suárez et al., 2007). 
Between 14-10 Ma, pulses of Andean uplift progressively formed a barrier to humid air masses from the east, generating the Arid Diagonal of South America (Riccardi and Rolleri, 1980). A northward shift in climate belts also increased the thermal gradient and strengthened the Southeast Pacific Anticyclone, so that the cold Humboldt Current came into being (Hinojosa and Villagrán, 1997; Zachos et al., 2001).

Our palynological studies in the Navidad Formation show an increase in angiosperms towards the top of the lower unit ( 16 Ma), together with a decrease in gymnosperms (Fig. 3). These Mixed Paleoflora (referred to as the 'Matanzas paleoflora' in figure 3 ) required conditions of high humidity with an annual precipitation of around $115 \mathrm{~cm}$ and mean annual temperatures of about $15^{\circ} \mathrm{C}$. In the upper unit (16-12 Ma), the relative proportion of angiosperms decreases, accompanied by an increase in gymnosperms. Belonging to the Subtropical Neogene Flora ('Pololos paleoflora' in figure 3), this suggests mean temperatures of $21-24^{\circ} \mathrm{C}$ and a mean annual rainfall of $44-91 \mathrm{~cm}$. There was thus a gradual increase in temperature and aridification between 16-12 Ma, which can be attributed to accelerated uplift in the Andes that prevented the spill-over of humid air from the east (Villagrán and Hinojosa, 1997; Hinojosa et al., 2011). Finally, pollen with affinity to modern Araucaria angustifolia (Bertol) and Araucaria araucana (Koch) occur together in both the lower and upper units, but these species are presently separated by the Arid Diagonal. This supports the development of the Arid Diagonal during the period 14-10 Ma, i.e., around the end of Navidad deposition. If the Navidad Formation were of Late Miocene-Pliocene age as argued by previous workers, these species would not have occurred together throughout the succession.

\section{Conclusions}

We consider the evidence pointing to an EarlyMiddle Miocene age for the Navidad Formation to be overwhelming, as $\mathrm{Sr}$ isotope and radiometric ages coincide with the chronostratigraphic ranges of macro- and microfossils, Andean tectonics and paleoclimatic events recognized worldwide. The only exception is the hitherto accepted Late Miocene-Pliocene age of five foraminifer species, which we consider should be revised in the light of the data presented above. They apparently evolved in the southeastern Pacific during the Early Miocene before radiating elsewhere from the Late Miocene to Pliocene. However, a formal change in the accepted range of these species would require a detailed study of their exact stratigraphic distribution, together with specific dating of the beds in which they occur, which is beyond the scope of this paper.

\section{Acknowledgments}

This research was funded by Projects Fondecyt 1060041 and 1090339 and the Millennium Institute of Ecology and Biodiversity (IEB), Grant P05-002 from Mideplan, PFB 23 from Conicyt. The first author is indebted to the Instituto Milenio de Ecología y Biodiversidad for a post-graduate grant. We are furthermore grateful to $\mathrm{R}$. Charrier, A. Rubilar, an anonymous reviewer, and the editor for their critical but very valuable comments, which helped us to improve this paper considerably.

\section{References}

Barron, J. 2003. Planktonic marine diatom record of the past 18 m.y.: appearances and extinctions in the Pacific and Southern Oceans. Diatom Research 18: 203-224.

Bertels, A. 1979. Paleobiogeografía de los foraminíferos del Cretácico Superior y Cenozoico de America del Sur. Ameghiniana 16: 273-356.

Bissig, T.; Clark, A.H.; Lee, J.K.W.; Hodgson, C.J. 2002. Miocene landscape evolution and geomorphologic controls on epithermal processes in the El Indio-Pascua $\mathrm{Au}-\mathrm{Ag}-\mathrm{Cu}$ Belt, Chile and Argentina. Economic Geology 97: 971-996.

Blow, W.H. 1959. Age, correlation and biostratigraphy of the Upper Tocuyo (San Lorenzo) and Pozón formations, eastern Falcón, Venezuela. Bulletin of American Paleontology 39: 67-252.

Boucot, A.J.; Theron, J.N. 2001. First Rhipidothyris (Brachiopoda) from southern Africa: Biostratigraphic, paleoecological, biogeographical significance. Journal of the Czech Geological Society 46: 155-160.

Campbell, K.; Bottjer, D. 1995. Brachiopods and chemosymbiotic bivalves in Phanerozoic hydrothermal vent and cold-seep paleoenvironments. Geology 23: 321-324.

Coles, G.P.; Whatley, R.C.; Moguilevsky, A. 1994. The ostracod genus Krithe from the Tertiary and Quaternary of the North Atlantic. Paleontology 37: 71-120.

Contardo, X.; Mena, F. 2012. Evidencias, caracterización e implicancias del primer seep fósil descubierto en 
la costa emergida de Chile central. In Congreso Geológico Chileno, No. 13, Actas: 663-665. Antofagasta.

Covacevich, C.V.; Frassinetti, C. 1980. El género Ficus en el Mioceno de Chile central con descripción de Ficus gayana sp. nov. Museo Nacional de Historia Natural, Boletín 37: 281-294.

Covacevich, V.; Frassinetti, D. 1986. El género Cancellaria en el Mioceno de Chile, con descripción de cuatro especies nuevas (Gastropoda: Cancellariidae). Revista Geológica de Chile 28-29: 33-67.

Covacevich, V.; Frassinetti, D. 1990. La Fauna de Lo Abarca: Hito biocronoestratigráfico y paleoclimático en el Terciario Superior marino de Chile Central. In Simposio del Terciario de Chile, No. 2, Actas: 51-71. Concepción.

Cushman, J.A.; Renz, H.H. 1947. The foraminiferal fauna of the Oliogocene Ste. Croix Formation of Trinidad. B.W.I. Cushman Laboratory of Foraminifer Research, Special Publication 22: $46 \mathrm{p}$.

Darwin, C. 1846. Geological observations on South America. Being the third part the geology of the voyage of the Beagle, under command of Capt. Fitzroy, R.N. during the years 1832 to 1836 . Smith, Elder and Co.: 279 p. London.

DeVries, T.J.; Frassinetti, D. 2003. Range extensions and biogeographic implications of Chilean Neogene molluscs found in Peru. Museo Nacional de Historia Natural de Chile, Boletín 52: 119-135.

Elewa, A.M.T. 2004. Quantitative analysis and paleoecology of Eocene Ostracoda and benthonic foraminifera from Gebel Mokattam, Cairo, Egypt. Paleogeography, Paleoclimatology, Paleoecology 211: 309-323.

Elgueta, S.; McDonough, M.; Le Roux, J.P.; Urqueta, E.; Duhart, P. 2005. Estratigrafía y Sedimentología de las Cuencas Terciarias de la Región de Los Lagos (39-4130'S). Servicio Nacional de Geología y Minería, Boletín 57: 50 p. Santiago.

Encinas, A. 2006. Estratigrafía y sedimentología de los depósitos marinos mio-pleistocénicos del área de Navidad (330' $-34^{\circ} 30^{\prime}$ S), Chile central: Implicaciones con respecto a la tectónica del antearco. Ph.D. Thesis (Unpublished), Universidad de Chile: 177 p.

Encinas, A.; Le Roux, J.P.; Buatois, L.A.; Nielsen, S.N.; Finger, K.L.; Fourtanier, E.; Lavenu, A. 2006. Nuevo esquema estratigráfico para los depósitos marinos pliocenos del área de Navidad ( $\left.33^{\circ} 00-34^{\circ} 30^{\prime} \mathrm{S}\right)$, Chile central. Revista Geológica de Chile 33 (2): 221-246.

Encinas, A.; Finger, K.; Nielsen, S.; Lavenu, A.; Buatois, L.; Peterson, D.; Le Roux, J.P. 2008. Rapid and major coastal subsidence during the late Miocene in south-central Chile. Journal of South American Earth Sciences 25: 157-175.

Feldmann, R.M.; Schweitzer, C.E.; Encinas, A. 2005. New decapods from the Navidad Formation (Miocene) of Chile. Journal of Crustacean Biology 25: 427-449.

Finger, K.L.; Encinas, A.; Nielsen, S.; Peterson, D. 2003. Microfaunal indications of late Miocene deep-water basins of the central coast of Chile. In Congreso Geológico Chileno, No. 10, CD Rom: 8 p. Concepción.

Finger, K.L.; Nielsen, S.N.; DeVries, T.J.; Encinas, A.; Peterson, D.E. 2007. Paleontologic evidence for sedimentary displacement in Neogene forearc basins of central Chile. Palaios 22: 3-16.

Gregory-Wodziki, K.M. 2000. Uplift history of the Central and Northern Andes: A review. Geological Society of America Bulletin 112: 1091-1105.

Groves, L.T.; Nielsen, S.N. 2003. A new Late Miocene Zonaria (Gastropodia: Cypraeidae) from central Chile. The Veliger 46: 351-354.

Guernet, C. 1998. Neogene and Pleistocene ostracodes, sites 595 and 960, Gulf of Guinea. In (Mascle, J.; Lohmann, G.P.; Moullade, M.; Editors), Chapter 38, Proceedings of the Ocean Drilling Program, Scientific Results 159, College Station, Texas: 525-531.

Hinojosa, L.F. 2005. Cambios climáticos y vegetacionales inferidos a partir de paleofloras cenozoicas del sur de Sudamérica. Revista Geológica de Chile 32: 95-115.

Hinojosa, L.F.; Villagrán, C. 1997. Historia de los bosques del sur de Sudamérica, I: antecedentes paleobotánicos, geológicos y climáticos del Terciario del cono sur de América. Revista Chilena de Historia Natural 70: 225-239.

Hinojosa, L.F.; Villagrán, C. 2005. Did South American Mixed Paleofloras evolve under thermal equability or in the absence of an effective Andean barrier during the Cenozoic? Paleogeography, Paleoclimatology, Paleoecology 217: 1-23.

Hinojosa, L.F.; Gutiérrez, N. 2009. Cambio climático y diversidad: El caso de la Formación Navidad, Mioceno de Chile central. In Congreso Geológico Chileno, No. 12, Actas 3: S10-21. Santiago.

Hinojosa, L.F.; Pérez, F.; Gaxiola, A.; Sandoval, I. 2011. Historical and phylogenetic constraints on the incidence of entire leaf margins: Insights from a new South American model. Global Ecology and Biogeography 20: 380-390.

Ibaraki, M. 1992. Planktonic foraminifera from the Navidad Formation, Chile: Their geologic age and paleoceanographic implications. In Centenary of Japanese Micropaleontology (Ishizaki, K.; Saito, 
T.; editors). Terra Scientific Publishing Company: 91-95. Tokio.

Kiel, S.; Campbell, K.; Gaillard, C. 2010. New and little known mollusks from ancient chemosynthetic environments. Zootaxa 2390: 26-48.

Kennet, J.P. 1982. Marine Geology. Graduate School of Oceanography, University of Rhode Island. PrenticeHall Inc.: 813 p.

Kennett, J.P.; Keller, G.; Srinivasan, M. 1985. Miocene planktonic foraminiferal biogeography and paleoceanograpic development of the Indo-Pacific region. Geological Society of America, Memoirs 166: 197-236.

Lagabrielle, Y.; Scalabrino, B.; Suárez, M.; Ritz, J.-F. 2010. Mio-Pliocene glaciations of Central Patagonia: New evidence and tectonic implications. Andean Geology 37: 276-299.

Le Roux, J.P. 2012a. A review of Tertiary climate changes in southern South America and the Antarctic Peninsula. Part 1: Oceanic conditions. Sedimentary Geology: 247/248: 1-20.

Le Roux, J.P. 2012b. A review of Tertiary climate changes in southern South America and the Antarctic Peninsula. Part 2. Continental conditions. Sedimentary Geology 247/248: 21-38.

Le Roux, J.P. ; Elgueta, S. 2000. Sedimentologic development of a Late Oligocene-Miocene forearc embayment, Valdivia Basin Complex, southern Chile. Sedimentary Geology 130: 27-44.

Le Roux, J.P.; Gómez, C.A.; Olivares, D.M.; Middleton, H. 2005. Determining the Neogene behavior of the Nazca Plate by geohistory analysis. Geology 33: 165-168.

Lipps, J.H. 1993. Fossil Prokaryotes and Protists. Blackwell Scientific Publications, Cambridge: 342 p.

Loutit, T.S.; Kennett, J.P.; Savin, S.M. 1983. Miocene equatorial and southwest Pacific paleoceanography from stable isotope evidence. Marine Micropaleontology 8: 215-233.

Malumián, N.; Camacho, H.H.; Gorrono, R. 1978. Molluscos del Terciario Inferior ('Magallense') de la Isla Grande de Tierra del Fuego (República Argentina). Ameghiniana 15: 265-284.

Martínez-Pardo, R. 1979. Hallazgo de foraminíferos miocénicos cerca de Puerto Aldea, Bahía de Tongoy, Provincia de Coquimbo, Chile. Revista Geológica de Chile 8: 65-78.

Martínez-Pardo, R. 1980. Hallazgo del Mioceneo marino en la Península de Mejillones, Antofagasta, Chile: Buenos Aires. In Congreso Argentino de Paleontología y Bioestratigrafía, No. 2 y Congreso Latinoamericano de Paleontología, No. 1, Actas 3: 57-66.
Martínez-Pardo, R. 1990. Major Neogene events of the Southeastern Pacific: the Chilean and Peruvian record. Paleogeography, Paleoclimatology, Paleoecology 77 : 263-278.

Martínez-Pardo, R.; Caro, R. 1980. Microfósiles silíceos de las diatomitas de Tongoy, Provincia de Coquimbo, Chile: Su significado biocronoestratigráfico, biocronogeológico, paleoecológico y paleogeográfico. Revista Geológica de Chile 10: 33-53.

McArthur, J.M.; Howard, R.J. 2004. Sr isotope stratigraphy. In A Geological Time Scale 2004 (Gradstein, F.M.; Ogg, J.G.; Smith, A.G.; editors). Cambridge University Press: 96-104. New York.

Meón, H.; Torres, T.; Martínez-Pardo, R. 1994. Sporopollinic analysis in the Navidad Formation near Navidad (Chile). In Congreso Geológico Chileno, No. 7, CD Rom: 488-490. Concepción.

Nielsen, S.N. 2003. Die marinen Gastropoden (exclusive Heterostropha) aus dem Miozän von Zentralchile: Hamburg, Ph.D. Thesis (Unpublished), University of Hamburg: 229 p.

Nielsen, S.N.; Frassinetti, D. 2003. New and little known species of Pseudoolividae (Gastropoda) from the Tertiary of Chile. The Nautilus 117: 91-96.

Nielsen, S.N.; Glodny, J. 2006. The middle Miocene climate optimum in central and southern Chile: ${ }^{87} \mathrm{Sr} /{ }^{86} \mathrm{Sr}$ isotope stratigraphy on warm-water molluscs. In Congreso Geológico Chileno, No. 11, Actas 2: 93-96. Antofagasta.

Nielsen, S.N.; DeVries, T.J.; Encinas, A.; Finger, K.L.; Peterson, D. 2003. Towards an understanding of the age of the Navidad Formation. In Congreso Geológico Chileno, No. 10, Actas, CD Rom: 7 p. Concepción.

Nielsen, S.N.; Frassinetti, D.; Bandel, K. 2004. Miocene Vetigastropoda and Neritimorpha (Mollusca, Gastropoda) of central Chile. Journal of South American Earth Sciences 17: 73-88.

Osorio, R. 1978. Ostracoda from the Navidad Formation (Miocene), Chile. Journal of the Faculty of Sciences, Hokkaido University: 4: 57-84.

Pemberton, S.G.; Spila, M.; Pulham, A.; Saunders, T.D.A.; MacEachern, J.; Robbins, D.M.; Sinclair I. 2001. Ichnology and sedimentology of shallow to marginal marine systems. Ben Nevis and Avalon reservoirs. Jeanne d'Arc Basin. Geological Association of Canada, Short Course Notes 15: 343 p.

Philippi, R.A. 1887. Los Fósiles Cuaternarios y Terciarios de Chile. Leipzig, Brockhaus: 256 p.

Riccardi, A.C.; Rolleri, E.E. 1980. Cordillera Patagónica Austral. In Geología Regional Argentina (Turner, 
J.C.M.; editor). Academia Nacional de Ciencias 2: 1173-1306. Córdoba.

Šimov, V.; Olšavský, M. 2007. Diplocraterion parallellum, Torell, 1870, and other trace fossils from the Lower Triassic succession of the Drienok Nappe, in the Western Carpathians, Slovakia. Bulletin of Geosciences 182: 165-173.

Srinivasan, M.S.; Kennett, J.P. 1981a. A review of Neogene planktonic foraminiferal biostratigraphy: applications in the equatorial and south Pacific. In The Deep Sea Drilling Project, a Decade of Progress (Warme, J.E.; Douglas, R.G.; Winterer, E.L.; editors). Society of Economic Paleontologist and Mineralogist (SEPM), Special Publication 32: 395-432.

Suárez, M.; De la Cruz, R; Bell, M. 2007. Geología del Área Ñireguao-Baño Nuevo, region Aisén del General Carlos Ibáñez del Campo. Servicio Nacional de Geología y Minería, Carta Geológica de Chile, Serie Geología Básica 108: 56 p. 1 mapa escala 1:100.000. Santiago, Chile.

Suárez, M.E.; Marquardt, C. 2001. Neogene selachians from the Bahía Inglesa Formation, north of Chile. In Jornadas Argentinas de Paleontología de Vertebrados, No. 17, Actas: p. 37. Esquel.

Suárez, M.E.; Encinas, A.; Ward, D. 2006. An early Miocene elasmobranch fauna from the Navidad Formation, central Chile, South America. Cainozoic Research 4: 3-18.

Tavera, J. 1960. El Plioceno de Bahía Horcón en la provincia de Valparaíso. Instituto de Geología, Facultad de Ciencias Físicas y Matemáticas, Universidad de Chile, Publicación No. 18: 347-367.

Tavera, J. 1979. Estratigrafía y paleontología de la Formación Navidad, Provincia de Colchagua, Chile (lat $\left.30^{\circ} 50^{\prime}-34^{\circ} \mathrm{S}\right)$. Boletín del Museo Nacional de Historia Natural de Chile 36: 176 p.

Troncoso, A. 1991. Paleomegaflora de la Formación Navidad, Miembro Navidad (Mioceno), en el área de Matanzas, Chile central occidental. Museo Nacional de Historia Natural de Chile, Boletín 42: 131-168.

Troncoso, A.; Suárez, M.; De la Cruz, R.; Palma-Heldt, S. 2002. Paleoflora de la Formación Ligorio Márquez (XI Región, Chile) en su localidad tipo: sistemática, edad e implicancias paleoclimáticas. Revista Geológica de Chile: 29 (1): 113-125.

Tsuchi, R. 1992. Neogene events in Japan and on the Pacific coast of South America. Revista Geológica de Chile 19: 67-73.

Van den Bold, W.A. 1958. Ostracoda of the Brasso Formation of Trinidad: Micropaleontology 4: 391-418.

Van den Bold, W.A. 1960. Eocene and Oligocene Ostracoda of Trinidad. Micropaleontology 6: 145-196.

Van den Bold, W.A. 1974. Taxonomic status of Cardobairdia (Van den Bold, 1960) and Abyssocypris n. gen: two deepwater ostracode genera of the Caribbean Tertiary. Geoscience and Man 6: 65-79.

Vermeij, G.J.; DeVries, T.J. 1997. Taxonomic remarks on Cenozoic pseudolivid gastropods from South America. The Veliger 40: 23-28.

Villagrán, C.; Hinojosa, L.F. 1997. Historia de los bosques del sur de Sudamérica, II: Análisis fitográfico. Revista Chilena de Historia Natural 70: 241-267.

Vossler, S.; Pemberton, S.G. 1988. Superabundant Chondrites: A response to storm buried organic material? Lethaia 21: 94.

Zachos, J.; Pagani, H.; Sloan, L.; Thomas, E.; Billups, K. 2001. Trends, rhythms, and aberrations in global climate: 65 Ma to present. Science 292: 686-693.

Manuscript received: November 24, 2011; revised/accepted: April 27, 2012; available online: June 22, 2012. 